\title{
HUBUNGAN ANTARA PENGETAHUAN TENTANG PEMBANGUNAN BERKELANJUTAN, EMPATI DAN KOMITMEN TERHADAP LINGKUNGAN DENGAN TANGGUNG JAWAB PESERTA PROGRAM PARTICIPANTS RESPONSIBILITY PADA BANK RAKYAT INDONESIA DALAM PELESTARIAN LINGKUNGAN
}

MOCH. SJAFAAT ISMAIL

Dosen STIE Ganesa Jakarta

\begin{abstract}
The objective of the research is to find out the relationship between knowledge of sustainable development, emphaty, and commitment toward environment with development program partisipants responsibility of environmental preservation. The sampel of this research were 73 persons which randomly taken. The data were analyzed by using regression and correlation techicques. Findings of the research concluded: 1) there is positive correlation between knowledge of the sustainable development with development program partisipants responsibility of environment preservation, 2) there is positive correlation between emphaty with development program partisipants responsibility of environment preservation, 3) there is positive correlation between commitment toward environment with development program partisipants responsibility of environmental preservation, and furthermore 4) there are correlation between knowledge of the sustainable development, emphaty, and commitment toward environment with development program partisipants responsibility of environmental preservation. Based on this development program partisipants result of responsibility of environmental preservation enhanced by increasing knowledge of the sustainable development, emphaty, and commitment toward environment.
\end{abstract}

Keywords: responsibility of environmental preservation, knowledge of sustainable development, emphaty, and commitment of environment.

\section{PENDAHULUAN}

Pembangunan yang dilaksa nakan oleh Pemerintah Indonesia tidak dapat dipisahkan dengan peran perbankan. Pendanaan program pembangunan terkait dengan peran lembaga perbankan. Lembaga perbankan menjadi mitra bagi pelaku pembangunan baik pihak pemerin-tah maupun swasta.

Hakikat pembangunan ber-tujuan untuk mensejahterakan ma-syrakat. Pada saat ini kaidah-kaidah pembangunan yang berkelanjutan telah diimplementasikan oleh subjek yang berwawasan lingkungan, dan bahkan menggunakan teknologi yang ramah lingkungan, namun kenyataan di lapang masih banyak ditemukan permasalahan lingkungan yang justru menjadi ancaman bagi manusia dan kelestarian lingkungan hidup itu sendiri. Ancaman terhadap kelestarian hidup bukan saja merugikan umat manusia pada saat ini, tetapi juga menjadi potensi bencana bagi kehidupan generasi yang akan datang.

Peran bank di dalam mendukung proses pembangunan di segala bidang tidak diragukan lagi. Penyaluran kredit oleh lembaga perbankan dalam pembiayaan pembangunan merupakan mata rantai awal terjadi perubahan lingkungan. Konversi hutan menjadi lahan perkebunan dan pertanian terjadi hampir di seluruh kawasan pulau-pulau 
di Indonesia. Luas hutan alam dari waktu ke waktu mengalami penyusutan.

Banyak hal yang menjadi penyebab rendahnya tanggung jawab manusia dalam pelestarian lingkungan yang bertumpu kepada aspek manusia. Pertama, kese-rakahan yang mengiringi pem-bangunan sosial dan ekonomi yang berwatak kapitalis. Kedua, kalangan ilmuwan berpengetahuan lemah dalam meyakinkan penyelenggara negara untuk membangun masyarakat yang cerdas dan menempatkan aspek pengelolaan lingkungan hidup secara kolektif pada posisi strategis. Ketiga, kelompok lapisan masyarakat miskin yang besar dan masih minim pengetahuan tentang lingkungan.

Teknologi yang tidak ramah lingkungan dan didorong oleh aspek keserakahan manusia sebagaimana disebutkan oleh Chiras (1991: 458), yang menyatakan bahwa manusia adalah makhluk yang mempunyai sifat biology imperialism, di mana secara kodrati manusia dikendalikan nafsu untuk menguasai segala benda, material yang diinginkannya. Sifat ini yang mendorong manusia dalam sudut pandang kebutuhan materi berperilaku serakah.

Banyak hal yang menjadi penyebab terjadinya kerusakan lingkungan yang pada dasarnya bertumpu kepada aspek manusianya. Pertama, keserakahan yang mengiringi pembangunan sosial dan ekonomi yang berwatak kapitalis. Kedua, lemahnya kalangan ilmuwan berpengetahuan untuk meyakinkan penyelenggara negara untuk mem-bangun masyarakat yang cerdas yang menempatkan aspek penge-lolaan lingkungan hidup secara kolektif pada posisi strategis. Ketiga, besarnya kelompok lapisan ma-syarakat miskin, masih minim penge-tahuan tentang lingkungan.

Manusia sebagai makhluk ciptaan Tuhan Yang Maha Esa yang sempurna, yang memiliki berbagai kelebihan-kelebihan dibandingkan dengan makhluk lainnya seharusnya menjadi pengelola lingkungan di planet bumi dengan penuh tanggung jawab. Apabila pengelolaan dapat dilakukan dengan baik, maka ling-kungan alam ini akan menjadi tempat hidup dan kehidupan yang berkesinambungan baik bagi manusia maupun makhluk hidup lainnya. Lingkungan hidup di bumi ini perlu dipelihara kelestariannya, dan apabila dimanfaatkan harus dilakukan secara baik dengan memper-hitungkan kebutuhan bagi generasi yang akan datang. Pengetahuan tentang pembangunan berkelanjutan penting dimiliki oleh aparatur yaitu peserta program pengembangan staf Bank Rakyat Indonesia (PPS BRI) yang banyak bersentuhan dengan pelaku usaha.

Peran bank dalam bermitra dengan swasta dalam pembangunan tidak disangsikan lagi, sehingga dalam pelayanan pihak bank dengan para pelaku pembangunan dalam hal pengajuan berbagai bentuk kegiatan pembangunan berlangsung komuni-kasi yang intensif. Kesempatan pihak bank melalui para stafnya mem-berikan edukasi kepada mitra kerja menjadi lebih terbuka. Berbagai proposal baik dari usaha kecil sampai usaha yang berskala besar akan menjadi sasaran pelayanan para pimpinan maupun staf bank. Dalam konteks demikian, maka bank melalui staf-stafnya dapat menjadi jalan untuk mewarnai aktivitas mitra dalam melakukan pembangunan di berbagai bidang agar menempatkan aspek lingkungan menjadi komponen yang diperhitungkan. Tanggung jawab dalam pelestarian lingkungan seseorang dipengaruhi oleh banyak faktor, seperti: pengetahuan seseorang tentang pembangunan berkelanjutan, per-hatian, komitmen, persepsi, sikap, empati, 
tingkat pendidikan, kesadaran diri, kepedulian terhadap lingkungan, dan sebagainya. Masing-masing faktor mempunyai andil terhadap kadar tanggung jawab seseorang.

Dari beberapa faktor yang dapat mempengaruhi seseorang dalam hal tanggung jawabnya terhadap pelestraian lingkungan, penulis mencoba mengungkap keterkaitan tiga variabel, yaitu: pengetahuan tentang pembangunan berkelanjutan, empati, dan komitmen terhadap lingkungan dengan tanggung jawab dalam pelestarian lingkungan.

\section{METODOLOGI PENELITIAN}

Penelitian ini dilaksanakan di Divisi Diklat BRI di Ragunan Jakarta Selatan. Unit analisisnya adalah Peserta
Program Pengem-bangan Staf BRI (PPS BRI). Penelitian ini dilaksanakan pada bulan April 2011.

Penelitian ini menggunakan metode survai. Menurut Singarimbun (1987:3), penelitian survai adalah penelitian yang mengambil sampel dari populasi dan menggu-nakan kuesioner sebagai alat pe-ngumpul data yang pokok. Penelitian survai dalam Disertasi ini bersifat explanatory atau confirmatory (penjelasaan).

Di dalam penelitian ini dijelaskan hubungan kausal antara variabel-variabel melalui pengujian hipotesis. Secara skematik maka konstelasi masalah dalam penelitian ini dapat digambarkan sebagai berikut:

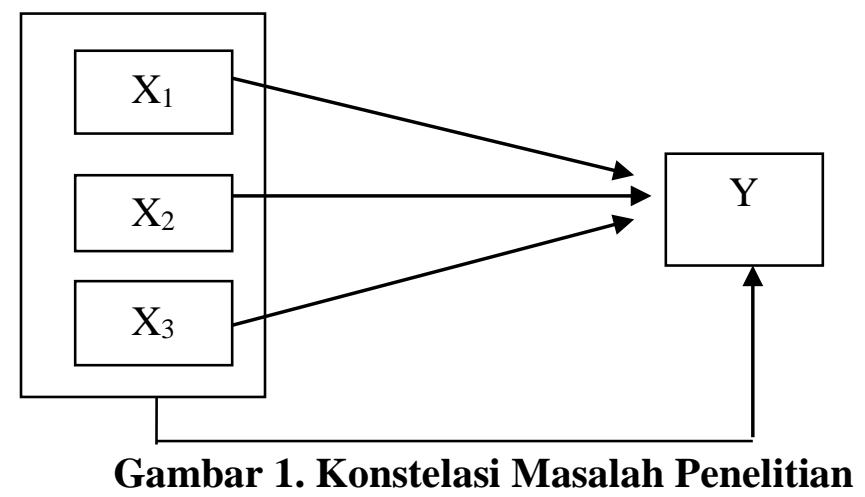

\section{Keterangan:}

$\mathrm{Y}=$ Tanggung jawab peserta PPS BRI dalam Pelestarian Lingkungan

$\mathrm{X}_{1}=$ Pengetahuan tentang Pembangunan Berkelanjutan

$\mathrm{X}_{2}=$ Empati; $\mathrm{X}_{3}=$ Komitmen terhadap Lingkungan

Populasi target dalam penelitian ini adalah seluruh peserta PPS BRI. Sedangkan populasi terjangkau adalah peserta PPS BRI Tahun Akademik 2010/2011 yang berjumlah 838 orang yang tersebar dalam 15 Batch. Istilah Batch di sini adalah periode seleksi penerimaan peserta PPS yang dilakukan oleh BRI.

Dalam penelitian ini teknik pengambilan sampel dilakukan dengan beberapa tahap, yaitu mengundi peserta berdasarkan Batch yang dalam hal ini diambil secara purposive random sampling sebanyak 3 Batch yang berjumlah 161 peserta PPS sesuai yang diizinkan poleh Divisi Diklat. Tiga Batch tersebut adalah Batch 20 (33 peserta), Batch 26 (42 peserta), dan Batch 29 (86 peserta).

Berdasarkan populasi terjangkau, maka jumlah sampel yang diambil secara

\begin{tabular}{|l|l|l|l|}
\hline Volume XIII & Nomor 01 & Maret 2012 & ISSN 1411-1829 \\
\hline
\end{tabular}


acak dengan undian adalah sebanyak 75 orang. Namun demikian, dalam pelaksanaan pengambilan data terdapat dua res-ponden yang jawabannya tidak lengkap sehingga tidak digunakan untuk dianalisis. Sampel penelitian yang layak untuk keperluan analisis dalam penelitian ini berjumlah 73 responden.

Instrumen yang digunakan dalam penelitian ini mencakup insrumen tes dan instrumen non-tes berupa angket. Secara bertahap data penelitian dianalisis melalui: 1) analisis deskriptif, 2) pengujian persyaratan analisis, dan 3) pengujian hipotesis. Persyaratan uji yang dilakukan antara lain uji normalitas dilakukan dengan Uji Kolmogorov Smirnov. Uji ini relevan terhadap pengujian hipotesis dengan uji-F melalui ANAVA (Putrawan, 1990: 133). Program analisis untuk mengolah data dalam penelitian ini digunakan software Excel dan SPSS versi 17.0 for Windows.

\section{HASIL PENELITIAN}

\section{Deskripsi Data Tanggung jawab}

Ukuran statistik yang dideskripsikan dalam penelitian ini diukur dari sampel penelitian yang berjumlah 73 responden. Adapun harga-harga sta-tistik deskriptif dapat diringkas da-lam tabel sebagai berikut:

Tabel 1. Ukuran Statistik Skor Tanggung jawab Peserta PPS BRI dalam Pelestarian Lingkungan

\begin{tabular}{|l|l|l|c|}
\hline No & Ukuran & Besaran Statistik & Harga \\
\hline \multirow{2}{*}{1.} & \multirow{2}{*}{ Gejala Pusat } & Mean & 83,92 \\
\cline { 3 - 4 } & & Median & 85,00 \\
\cline { 3 - 4 } & & Modus & 86,00 \\
\hline \multirow{2}{*}{2.} & \multirow{2}{*}{ Keragaman } & Skor Maksimum & 110,00 \\
\cline { 3 - 4 } & & Skor Minimum & 59,00 \\
\cline { 3 - 4 } & & Rentang & 51,00 \\
\hline 3. & Variabilitas & Simpangan Baku & 10,73 \\
\hline
\end{tabular}

Dari Tabel 1 khususnya pada ukuran gejala pusat yaitu: mean $=83,92$, median $=85,00$, dan modus $=86,00$ ketiganya ternyata tidak sama besar sehingga kurva distribusi normal data penelitian ini tidak simetris. Ukuran median dan mean selisihnya tidak besar. Sifat mean dan median lebih stabil dibandingkan modus, berarti perbedaan yang tidak terlalu besar ini masih memungkinkan sebaran data mendekati simetris.

\section{Deskripsi Data Pengetahuan tentang Berkelanjutan Pembangunan}

Ukuran statistik yang dideskripsikan dalam penelitian ini diukur dari sampel penelitian yang ber-jumlah 73 responden. Adapun harga-harga statistik deskriptif dapat di-ringkas dalam tabel sebagai berikut:

Tabel 2. Ukuran Statistik Skor Pengetahuan tentang Pembangunan

Berkelanjutan

\begin{tabular}{|l|l|l|c|}
\hline No & Ukuran & Besaran Statistik & Harga \\
\hline \multirow{3}{*}{1.} & \multirow{2}{*}{ Gejala Pusat } & Mean & 16,66 \\
\cline { 3 - 4 } & & Median & 17,00 \\
\cline { 3 - 4 } & & Modus & 19,00 \\
\hline \multirow{2}{*}{2.} & \multirow{2}{*}{ Keragaman } & Skor Maksimum & 20,00 \\
\cline { 3 - 4 } & & Skor Minimum & 12,00 \\
\cline { 3 - 4 } & & Rentang & 8,00 \\
\hline 3. & Variabilitas & Simpangan Baku & 2,13 \\
\hline
\end{tabular}

17 
Dari Tabel 2 khususnya pada ukuran gejala pusat yaitu: mean $=16,66$, median= 17,00, dan modus $=19,00$ ketiganya ternyata tidak sama besar sehingga kurva distribusi nor-mal data penelitian ini tidak simetris. Ukuran median dan mean selisihnya tidak besar, berarti perbedaan yang tidak terlalu besar ini masih me- mungkinkan sebaran data mendekati simetris.

\section{Deskripsi Data Empati}

Ukuran statistik yang dideskripsikan dalam penelitian ini diukur dari sampel penelitian yang berjumlah 73 responden. Adapun hargaharga statistik deskriptif dapat di-ringkas dalam tabel sebagai berikut:

Tabel 3. Ukuran Statistik Skor Empati

\begin{tabular}{|l|l|l|c|}
\hline No & Ukuran & Besaran Statistik & Harga \\
\hline \multirow{2}{*}{1.} & \multirow{2}{*}{ Gejala Pusat } & Mean & 39,40 \\
\cline { 3 - 4 } & & Median & 40,00 \\
\cline { 3 - 4 } & & Modus & 45,00 \\
\hline \multirow{2}{*}{2.} & \multirow{2}{*}{ Keragaman } & Skor Maksimum & 45,00 \\
\cline { 3 - 4 } & & Skor Minimum & 33,00 \\
\cline { 3 - 4 } & & Rentang & 12,00 \\
\hline 3. & Variabilitas & Simpangan Baku & 4,18 \\
\hline
\end{tabular}

Dari Tabel 3 khususnya pa-da ukuran gejala pusat yaitu: mean $=39,40$, median $=40,00$, dan modus $=45,00$ ketiganya ternyata tidak sama besar sehingga kurva distribusi normal data penelitian ini tidak simetris. Ukuran median dan mean selisihnya tidak besar, berarti perbedaan yang tidak terlalu besar ini masih memberikan kemungkinan sebaran data mendekati simetris.

\section{Deskripsi Data Komitmen terhadap Lingkungan}

Ukuran statistik yang dideskripsikan dalam penelitian ini diukur dari sampel penelitian yang berjumlah 73 responden. Adapun harga-harga statistik deskriptif dapat di-ringkas dalam tabel sebagai berikut:

Tabel 4. Ukuran Statistik Skor Komitmen terhadap Lingkungan

\begin{tabular}{|l|l|l|c|}
\hline No & Ukuran & Besaran Statistik & Harga \\
\hline \multirow{2}{*}{1.} & \multirow{2}{*}{ Gejala Pusat } & Mean & 89,07 \\
\cline { 3 - 4 } & & Median & 88,00 \\
\cline { 3 - 4 } & & Modus & 70,00 \\
\hline 2. & \multirow{2}{*}{ Keragaman } & Skor Maksimum & 115,00 \\
\cline { 3 - 4 } & & Skor Minimum & 62,00 \\
\cline { 3 - 4 } & & Rentang & 8,00 \\
\hline 3. & Variabilitas & Simpangan Baku & 2,07 \\
\hline
\end{tabular}

Dari Tabel 4 khususnya pa-da ukuran gejala pusat yaitu: mean $=16,68$, median $=17,00$, dan modus $=19,00$ ketiganya ternyata tidak sama besar sehingga kurva distribusi normal data penelitian ini tidak simetris. Ukuran median dan mean selisihnya tidak besar, berarti per-bedaan yang tidak terlalu besar ini masih memungkinkan sebaran data mendekati simetris.

\section{Pengujian Hipotesis \\ Hipotesis Pertama:}

Besarnya harga konstanta dan koefisien yang dicari dari pengujian hipotesis ini digunakan untuk membangun model persamaan regresi empirik. Persamaan regresi linear

\begin{tabular}{|l|l|l|l|}
\hline Volume XIII & Nomor 01 & Maret 2012 & ISSN 1411-1829 \\
\hline
\end{tabular}


sederhana empirik yang diperoleh adalah $\hat{\mathrm{Y}}=12,712+0,047 \mathrm{X}_{1}$. Melalui hasil uji hipotesis pertama ini diperoleh koefisien korelasi nihil antara variabel bebas $\mathrm{X}_{1}$ dengan variabel terikat $\mathrm{Y}\left(\mathrm{r}_{\mathrm{y} 1}\right)$ sebesar 0,237 . Hasil uji keberartian regresi $\mathrm{Y}$ atas $\mathrm{X}_{1}$ dapat diringkas hasilnya sebagai berikut:

Tabel 5. Ringkasan Uji Keberartian dan Linearitas Regresi melalui Analisis Varians Regresi $\mathrm{Y}$ atas $\mathrm{X}_{1}$

\begin{tabular}{|c|c|c|c|c|c|c|}
\hline \multirow{2}{*}{$\begin{array}{l}\text { Sumber } \\
\text { Variasi }\end{array}$} & \multirow{2}{*}{$\begin{array}{l}\text { Derajat } \\
\text { Kebebas-an } \\
\text { (dk) }\end{array}$} & \multirow{2}{*}{$\begin{array}{l}\text { Jumlah } \\
\text { Kuadrat } \\
\text { (JK) }\end{array}$} & \multirow{2}{*}{$\begin{array}{l}\text { Kuadrat } \\
\text { Tengah } \\
\text { (KT) }\end{array}$} & \multirow[b]{2}{*}{ Fhitung } & \multicolumn{2}{|c|}{$F_{\text {tabel }}$} \\
\hline & & & & & $\alpha=0,05$ & $\alpha=\mathbf{0 , 0 1}$ \\
\hline Total & 73 & 5223374,00 & & & & \\
\hline $\begin{array}{l}\text { Koef. (a) } \\
\text { Regresi b/a) } \\
\text { Sisa }\end{array}$ & $\begin{array}{r}1 \\
1 \\
71\end{array}$ & $\begin{array}{r}5223047,662 \\
18,334 \\
308,104\end{array}$ & $\begin{array}{r}18,334 \\
4,339\end{array}$ & $4,22^{*}$ & 4,00 & 7,08 \\
\hline $\begin{array}{l}\text { Tuna Cocok } \\
\text { Galat }\end{array}$ & $\begin{array}{l}32 \\
39\end{array}$ & $\begin{array}{l}144,804 \\
163,300\end{array}$ & $\begin{array}{l}4,525 \\
4,187\end{array}$ & $1,08^{\mathrm{ns}}$ & 2,09 & 2,95 \\
\hline
\end{tabular}

Keterangan:

**) Persamaan Regresi Sangat berarti; ns = non signifikan.

Berdasarkan hasil uji hipotesis pertama yang hasilnya diringkas dalam Tabel 5 diperoleh kenyataan bahwa: uji signifikansi persamaan regresi $\mathrm{Y}$ atas $\mathrm{X}_{1}$ yang diperoleh $\hat{\mathrm{Y}}=12,712+0,047 \mathrm{X}_{1}$ menunjukkan harga $F_{\text {hitung }}=4,22>\mathrm{F}_{(0,05)}$ $(1 ; 71)=4,00$, ber-arti tolak Ho pada $\alpha=$ 0,05 . Dengan demikian persamaan regresi linear sederhana $\hat{\mathrm{Y}}=$ $12,712+0,047 \mathrm{X}_{1}$ adalah signifikan. Pada uji linearitas re-gresi $\mathrm{Y}$ atas $\mathrm{X}_{1}$ diperoleh $F_{\text {hitung }}=1,08<F_{(0,05)}(7: 64)=2,09$, berarti terima Ho pada $\alpha=0,05$. Hasil uji menunjukkan bentuk hubungan linear dari per-samaan regresi linear sederhana $\hat{Y}=12,712+0,047 \mathrm{X}_{1}$ adalah signifikan.

Hasil uji ini dilanjutkan dengan menghitung kekuatan korelasi parsil, mengingat persamaan regresi sebagai temuan dalam pe nelitian ini signifikan. Berdasarkan hasil perhitungan uji signifikansi harga-harga koefisien korelasi parsil dapat diringkas dalam tabel berikut

\section{Tabel 6. Hasil Uji Signifikansi Harga Koefisien Korelasi Parsil antara Variabel $\mathbf{X}_{1}$ dengan $\mathbf{Y}$}

\begin{tabular}{|l|l|l|l|l|l|}
\hline No & Korelasi Parsil & Harga $\mathbf{r}$ & $\mathbf{t}_{\text {hitung }}$ & $\mathbf{t}_{\text {tabel }}$ & \multicolumn{1}{|c|}{ Kesimpulan } \\
\hline 1. & $\mathrm{r}_{\mathrm{y} 1.2}$ & 0,302 & $2,67^{* *}$ & 2,63 & Sangat signifikan \\
\hline 2. & $\mathrm{r}_{\mathrm{y} 1.3}$ & 0,224 & $1,89^{*}$ & 1,65 & Signifikan \\
\hline 3. & $\mathrm{r}_{\mathrm{y} 1.23}$ & 0,212 & $2,12^{*}$ & 1,65 & Signifikan \\
\hline
\end{tabular}

Keterangan: $\mathrm{t}_{\text {tabel }}$ adalah $\mathrm{t}_{(0,05)(73)}=1,65 ; \mathrm{t}_{(0,01)(73)}=2,63$

*) signifikan; dan **) sangat signifikan.

Harga indeks determinasi yang diambil dari $R$ square menun-jukkan sebesar 0,056. Ini berarti besarnya kontribusi variabel penge-tahuan tentang pembangunan berke-lanjutan $\left(\mathrm{X}_{1}\right)$ terhadap variasi skor tanggung jawab peserta PPS BRI dalam pelestarian lingkungan adalah 5,6\%.

\section{Hipotesis Kedua:}

Besarnya harga konstanta dan koefisien yang dicari dari peng-ujian 
hipotesis ini digunakan untuk membangun model persamaan regresi empirik. Persamaan regresi linear sederhana empirik yang dipe-roleh adalah $\hat{\mathrm{Y}}=54,361+0,75 \mathrm{X}_{2}$. Melalui hasil uji korelasi nihil antara varaibel bebas $\mathrm{X}_{2}$ dengan variabel terikat $\mathrm{Y}\left(\mathrm{r}_{\mathrm{y} 2}\right)$ sebesar 0,292 . Hasil uji keberartian regresi $\mathrm{Y}$ atas $\mathrm{X}_{2}$ dapat diringkas hasilnya sebagai berikut:

hipotesis kedua ini diperoleh koefisien

Tabel 7. Ringkasan Uji Keberartian dan Linearitas Regresi melalui Analisis

\begin{tabular}{|c|c|c|c|c|c|c|}
\hline \multirow{3}{*}{$\begin{array}{l}\text { Sumber } \\
\text { Variasi }\end{array}$} & \multirow{3}{*}{$\begin{array}{l}\text { Derajat } \\
\text { Kebebas-an } \\
\text { (dk) }\end{array}$} & \multicolumn{5}{|c|}{ Varians Regresi $\mathrm{Y}$ atas $\mathrm{X}_{2}$} \\
\hline & & \multirow{2}{*}{$\begin{array}{l}\text { Jumlah } \\
\text { Kuadrat (JK) }\end{array}$} & \multirow{2}{*}{$\begin{array}{l}\text { Kuadrat } \\
\text { Tengah } \\
\text { (KT) }\end{array}$} & \multirow[b]{2}{*}{ Fhitung } & \multicolumn{2}{|c|}{$F_{\text {tabel }}$} \\
\hline & & & & & $\alpha=\mathbf{0 , 0 5}$ & $\alpha=0,01$ \\
\hline Total & 73 & 5223374,000 & & & & \\
\hline $\begin{array}{l}\text { Koef. (a) } \\
\text { Regresi b/a) } \\
\text { Sisa }\end{array}$ & $\begin{array}{c}1 \\
1 \\
71\end{array}$ & $\begin{array}{r}5215080,493 \\
707,743 \\
585,764\end{array}$ & $\begin{array}{l}707,743 \\
106,692\end{array}$ & $6,62^{*}$ & 4,00 & 7,08 \\
\hline Tuna Cocok & $\begin{array}{l}11 \\
11 \\
22\end{array}$ & $\begin{array}{r}585, / 64 \\
581,241 \\
7004522\end{array}$ & 178,330 & $0,45^{\mathrm{ns}}$ & 2,09 & 2,95 \\
\hline
\end{tabular}

Keterangan:

*) Persamaan Regresi berarti; ns = non signifikan.

Berdasarkan hasil uji hipote-sis kedua yang hasilnya diringkas dalam Tabel 7 diperoleh kenyataan bahwa: uji signifikansi persamaan regresi $\mathrm{Y}$ atas $\mathrm{X}_{2}$ yang diperoleh $\hat{\mathrm{Y}}=54,361+0,75 \mathrm{X}_{2}$ menun-jukkan harga $F_{\text {hitung }}=6,62>\mathrm{F}_{(0,05)}$ $(1 ; 71)=4,00$, berarti tolak Ho pada $\alpha=$ 0,05 . Dengan demikian persamaan regresi linear sederhana $\hat{Y}=54,361+$ $0,75 \mathrm{X}_{2}$ ada-lah signifikan. Pada uji linearitas regresi $\mathrm{Y}$ atas $\mathrm{X}_{2}$ diperoleh $F_{\text {hitung }}=0,45<F_{(0,05)}(11: 22)=2,09$, berarti terima Ho pada $\alpha=0,05$. Hasil uji menunjukkan bentuk hubungan linear dari persamaan regresi linear sederhana $\hat{\mathrm{Y}}=54,361+0,75 \mathrm{X}_{2}$ adalah signifikan.

Hasil uji ini dilanjutkan dengan menghitung kekuatan korelasi parsil, mengingat persamaan regresi sebagai temuan dalam penelitian penelitian ini signifikan. Berdasarkan hasil perhitungan uji signifikansi harga-harga koefisien korelasi parsil dapatdiringkas dalam tabel berikut:

Tabel 8. Hasil Uji Signifikansi Harga-harga Koefisien Korelasi Parsil antara Variabel $\mathrm{X}_{2}$ dengan $\mathrm{Y}$

\begin{tabular}{|l|l|l|l|l|l|}
\hline No & Korelasi Parsil & Harga $\mathbf{r}$ & thitung & $\mathbf{t}_{\text {tabel }}$ & \multicolumn{1}{|c|}{ Kesimpulan } \\
\hline 1. & $\mathrm{r}_{\mathrm{y} 2.1}$ & 0,304 & $2,82^{* *}$ & 2,63 & Sangat signifikan \\
\hline 2. & $\mathrm{r}_{\mathrm{y} 2.3}$ & 0,276 & $2,52^{*}$ & 1,65 & Signifikan \\
\hline 3. & $\mathrm{r}_{\mathrm{y} 2.13}$ & 0,289 & $1,77^{*}$ & 1,65 & Signifikan \\
\hline
\end{tabular}

Keterangan:

$\mathrm{t}_{\text {tabel }}$ adalah $\mathrm{t}_{(0,05)(73)}=1,65 ;$ dan $\mathrm{t}_{(0,01)(73)}=2,63$

*) signifikan ; dan **) sangat signifikan.

Berdasarkan pengujian signifikansi koefisien korelasi parsil di atas, secara keseluruhan diperoleh bahwa harga $t_{\text {hitung }}>t_{\text {tabel}}$. Dengan demikian kekuatan hubungan yang ditunjukkan dengan harga koefisien korelasi antara empati dengan tanggung jawab dalam pelestarian ling-kungan benar-benar signifikan.

\begin{tabular}{|l|l|l|l|} 
Volume XIII & Nomor 01 & Maret 2012 & ISSN 1411-1829 \\
\hline
\end{tabular}


Untuk memperoleh gambar-an kontribusi variabel $\mathrm{X}_{2}$ terhadap variabel $\mathrm{Y}$, maka dihitung harga indeks determinasi yaitu kuadrat dari harga koefisien korelasi nihil $\left(\mathrm{r}_{\mathrm{y} 2}\right)^{2}$. Harga indeks determinasi yang diambil dari $R$ square menunjukkan sebesar 0,085. Ini berarti besarnya kontribusi variabel empati $\left(\mathrm{X}_{2}\right)$ terhadap variasi skor tanggung jawab peserta PPS BRI dalam pelestarian lingkungan adalah 8,5\%.

\section{Hipotesis Ketiga:}

Besarnya harga konstanta dan koefisien yang dicari dari pe-ngujian hipotesis ini digunakan untuk membangun model persamaan regresi empirik. Persamaan regresi linear sederhana empirik yang diperoleh dalam penelitian ini adalah $\hat{\mathrm{Y}}=67,366+0,86 \mathrm{X}_{3}$. Melalui hasil uji hipotesis ketiga ini diperoleh koefisien korelasi yang menunjukkan kekuatan hubungan nihil antara variabel bebas $\mathrm{X}_{3}$ dengan variabel terikat $\mathrm{Y}\left(\mathrm{r}_{\mathrm{y} 3}\right)$ sebesar 0,231. Hasil uji keberartian regresi $\mathrm{Y}$ atas $\mathrm{X}_{3}$ dapat diringkas hasilnya sebagai berikut:

Tabel 9. Ringkasan Uji Keberartian dan Linearitas Regresi melalui Analisis Varians Regresi $\mathrm{Y}$ atas $\mathrm{X}_{3}$

\begin{tabular}{|c|c|c|c|c|c|c|}
\hline \multirow{2}{*}{$\begin{array}{l}\text { Sumber } \\
\text { Variasi }\end{array}$} & \multirow{2}{*}{$\begin{array}{c}\text { Derajat } \\
\text { Kebebasan } \\
\text { (dk) }\end{array}$} & \multirow{2}{*}{$\begin{array}{c}\text { Jumlah } \\
\text { Kuadrat } \\
\text { (JK) }\end{array}$} & \multirow{2}{*}{$\begin{array}{c}\text { Kuadrat } \\
\text { Tengah } \\
\text { (KT) }\end{array}$} & \multirow[b]{2}{*}{ Fhitung } & \multicolumn{2}{|c|}{$F_{\text {tabel }}$} \\
\hline & & & & & $\alpha=0,05$ & $\alpha=0,01$ \\
\hline Total & 73 & 5223374,000 & & & & \\
\hline $\begin{array}{l}\text { Koef. (a) } \\
\text { Regresi b/a) } \\
\text { Sisa }\end{array}$ & $\begin{array}{r}1 \\
1 \\
71\end{array}$ & $\begin{array}{r}5215880,493 \\
442,549 \\
7050,958\end{array}$ & $\begin{array}{l}442,549 \\
110,577\end{array}$ & $4,002^{*}$ & 4,00 & 7,08 \\
\hline $\begin{array}{l}\text { Tuna Cocok } \\
\text { Galat }\end{array}$ & $\begin{array}{l}33 \\
38\end{array}$ & $\begin{array}{l}3580,291 \\
4270,667\end{array}$ & $\begin{array}{l}108,494 \\
112,386\end{array}$ & $0,97^{\mathrm{ns}}$ & 2,09 & 2,95 \\
\hline
\end{tabular}

\section{Keterangan:}

**) Persamaan Regresi Sangat berarti.

ns $=$ non signifikan.

Berdasarkan hasil uji hipotesis ketiga yang hasilnya diringkas dalam Tabel 9 diperoleh kenyataan bahwa: uji signifikansi persamaan regresi $\mathrm{Y}$ atas $\mathrm{X}_{3}$ yang diperoleh $\hat{\mathrm{Y}}=67,366+0,86 \mathrm{X}_{3}$ menunjukkan harga $F_{\text {hitung }}=4,002>\mathrm{F}_{(0,05)}$ $(1 ; 71)=4,00$, ber-arti tolak Ho pada $\alpha=$ 0,05 . Dengan demikian persamaan regresi linear sederhana $\hat{Y}=$ $67,355+0,86 X_{3}$ ada-lah signifikan. Pada uji linearitas regresi $\mathrm{Y}$ atas $\mathrm{X}_{3}$ diperoleh $F_{\text {hitung }}=0,97<F_{(0,05)}(7: 64)=2,09$, berarti terima Ho pada $\alpha=0,05$. Hasil uji menunjukkan bentuk hubungan linear dari persamaan regresi linear sederhana $\hat{Y}=67,366+0,86 X_{3}$ adalah signifikan.

Hasil uji ini dilanjutkan dengan menghitung kekuatan korelasi parsil, mengingat persama-an regresi sebagai temuan dalam penelitian penelitian ini signifikan. Berdasarkan hasil perhitungan uji signifikansi harga-harga koefisien korelasi parsil dapat diringkas dalam tabel berikut:

\begin{tabular}{|l|l|l|l|}
\hline Volume XIII & Nomor 01 & Maret 2012 & ISSN 1411-1829 \\
\hline
\end{tabular}


Tabel 10. Hasil Uji Signifikansi Harga-harga Koefisien Korelasi Parsil antara Variabel $\mathrm{X}_{3}$ dengan $\mathrm{Y}$

\begin{tabular}{|l|l|l|l|l|l|}
\hline No & Korelasi Parsil & Harga $\mathbf{r}$ & thitung $_{\text {Kesimpulan }}$ & $\mathbf{t}_{\text {tabel }}$ & Kesifikan \\
\hline 1. & $\mathrm{r}_{\mathrm{y} 3.1}$ & 0,212 & $1,83^{*}$ & 1,65 & Signifikan \\
\hline 2. & $\mathrm{r}_{\mathrm{y} 3.2}$ & 0,210 & $1,85^{*}$ & 1,65 & Signifkan \\
\hline 3. & $\mathrm{r}_{\mathrm{y} 3.12}$ & 0,202 & $1,77^{*}$ & 1,65 & Signifikan \\
\hline
\end{tabular}

Keterangan:

$\mathrm{t}_{\text {tabel }}$ adalah $\mathrm{t}_{(0,05)(73)}=1,65$

*) signifikan.

Berdasarkan pengujian signifikansi koefisien korelasi parsil di atas, secara keseluruhan diperoleh bahwa $t_{\text {hitung }}>t_{\text {tabel }}$ pada $\alpha=0,05$. Dengan demikian koefisien korelasi yang menyatakan hubungan antara komitmen terhadap lingkungan dengan tanggung jawab peserta PPS BRI dalam pelestarian lingkungan benar-benar signifikan.

Untuk memperoleh gambar-an kontribusi variabel $\mathrm{X}_{3}$ terhadap variabel $\mathrm{Y}$, maka dihitung harga indeks determinasi yaitu kuadrat dari harga koefisien korelasi nihil $\left(\mathrm{r}_{\mathrm{y} 3}\right)^{2}$.

Harga indeks determinasi yang diambil dari $R$ square menunjukkan sebesar 0,053. Ini berarti besarnya kontribusi variabel komitmen terhadap lingkungan $\left(\mathrm{X}_{3}\right)$ terhadap variasi skor tanggung jawab peserta PPS BRI dalam pelestarian lingkungan adalah 5,3\%.

\section{Hipotesis Keempat:}

Besarnya harga konstanta dan koefisien yang dicari dari pengujian hipotesis ini digunakan untuk membangun model per-samaan regresi empirik. Persamaan regresi linear jamak empirik yang diperoleh adalah $\hat{\mathrm{Y}}=$ $23,665+1,148 \mathrm{X}_{1}+0,702 \mathrm{X}_{2}+0,151 \mathrm{X}_{3}$. Koefisien korelasi jamak (Ry) yang diperoleh dari pengujian hipotesis keempat adalah sebesar 0,421. Hasil uji keberartian persamaan regresi tersebut adalah sebagai berikut:

Tabel 11. Uji Keberartian Regresi $Y$ atas $X_{1}, X_{2}$, dan $X_{3}$ melalui Daftar Anava

\begin{tabular}{|c|c|c|c|c|c|c|}
\hline \multirow{2}{*}{$\begin{array}{l}\text { Sumber } \\
\text { Variasi }\end{array}$} & \multirow{2}{*}{$\begin{array}{l}\text { Derajat } \\
\text { Kebebas- } \\
\text { an (dk) }\end{array}$} & \multirow{2}{*}{$\begin{array}{l}\text { Jumlah } \\
\text { Kuadrat } \\
\text { (JK) }\end{array}$} & \multirow{2}{*}{$\begin{array}{l}\text { Kuadrat } \\
\text { Tengah } \\
\text { (KT) }\end{array}$} & \multirow[b]{2}{*}{ F $_{\text {hitung }}$} & \multicolumn{2}{|l|}{$F_{\text {tabel }}$} \\
\hline & & & & & $\alpha=0,05$ & $\alpha=\mathbf{0 , 0 1}$ \\
\hline Regresi & 3 & 1470,074 & 490,058 & $4,956^{* *}$ & 2,76 & 4,13 \\
\hline Sisa & 69 & 6823,333 & 98,889 & & & \\
\hline
\end{tabular}

Keterangan:

**) Sangat signifikan.

Hasil uji keberartian persamaan regresi $\hat{\mathrm{Y}}=23,665+1,148 \mathrm{X}_{1}+0,702 \mathrm{X}_{2}+$ $0,151 X_{3}$ sebagai-mana dirangkum dalam Tabel 14 adalah sangat signifikan. Untuk memperoleh gambaran kontribusi ketiga variabel bebas terhadap variasi variabel terikat, maka dihitung harga indeks determinasi $(\mathrm{Ry})^{2}$ yang hasilnya sebesar
0,177. Ini berarti kon-tribusi pengetahuan tentang pem-bangunan berkelanjutan $\left(\mathrm{X}_{1}\right)$, empati $\left(\mathrm{X}_{2}\right)$, dan komitmen terhadap lingkungan $\left(\mathrm{X}_{3}\right)$ secara bersama-sama terhadap variasi yang terjadi pada skor tanggung jawab peserta PPS BRI dalam pelestarian lingkungan (Y) sebesar 17,7\%. Dari

22

Volume XIII 
pengujian hipotesis penelitian kesatu, kedua, ketiga, dan keempat diperoleh kenyataan bahwa keseluruhan hipotesis teruji. Dengan hasil uji ini berarti tidak ada hasil uji hipotesis yang bertentangan dengan kerangka berpikir yang dikembangkan berdasarkan kajian teoretik. Oleh karena itu hasil penelitian ini dapat dipandang menjadi memperkaya khasanah pengetahuan ilmiah khususnya berkaitan dengan tanggung jawab dalam pelestarian lingkungan dengan memperhitungkan faktor pengetahuan tentang pembangunan berkelanjutan, empati, dan komitmen terhadap lingkungan.

\section{KESIMPULAN}

Secara umum, pengetahuan tentang pembangunan berkelanjut-an, empati, dan komitmen terhadap lingkungan baik secara sendiri mau-pun bersama-sama menentukan tinggi rendahnya tanggung jawab peserta PPS BRI dalam pelestarian lingkungan.

Dengan mengontrol terha-dap masing-masing variabel bebas, koefisien korelasi masing-masing variabel bebas dengan tanggung jawab peserta PPS BRI dalam pelestarian lingkungan secara murni tetap signifikan. Hubungan yang paling kuat di antara ketiga variabel bebas terdapat pada hubungan antara empati dengan tanggung jawab peserta PPS BRI dalam pelestarian lingkungan.

Berdasarkan analisis data hasil penelitian ini, dapat ditarik kesimpulan sebagai berikut:

Pertama, makin tinggi pengetahuan tentang pembangunan berkelanjutan maka semakin tinggi pula tanggung jawab peserta PPS BRI dalam pelestarian lingkungan.

Kedua, makin tinggi empati maka semakin tinggi pula tanggung jawab peserta PPS BRI dalam pelestarian lingkungan.
Ketiga, makin tinggi komitmen terhadap lingkungan maka semakin tinggi pula tanggung jawab peserta PPS BRI dalam pelestarian lingkungan.

$$
\text { Keempat, makin tinggi }
$$

pengetahuan tentang pembangunan berkelanjutan, empati, dan komitmen terhadap lingkungan maka semakin tinggi pula tanggung jawab peserta PPS BRI dalam pelestarian lingkungan.

\section{IMPLIKASI}

Berdasarkan kesimpulan penelitian di atas, maka sebagai konsekuensi untuk meningkatkan tanggung jawab peserta PPS BRI dalam pelestarian lingkungan dapat dilakukan dengan meningkatkan pengetahuan tentang pembangunan berkelanjutan, empati, dan komitmen terhadap lingkungan baik secara sendiri maupun bersama-sama.

\section{Upaya Peningkatan Tanggung Jawab Peserta PPS BRI dalam Pelestarian Lingkungan me-lalui Peningkatan Pengetahu-an tentang Pembangunan Berkelanjutan}

Dalam konteks penelitian ini, untuk memberikan kesempatan yang luas kepada peserta PPS BRI agar dapat meningkat pengetahuannya tentang pembangunan berkelanjutan dapat dilakukan sebagai berikut:

Pertama, mengintegrasikan materi pengetahuan tentang pembangunan berkelanjutan ke dalam silabus mata ajar pendidikan dan pelatihan tanpa harus merubah mata ajar yang telah ada.

Kedua, memperkaya sumber bacaan di perpustakaan dengan sumber informasi baik berupa buku maupun publikasi lain seperti jurnal, majalah ilmiah, koran kampus, dan sebagainya yang memfokuskan tentang materi berkaitan dengan pengetahuan tentang pembangunan berkelanjutan.

Ketiga, sejalan dengan pencitraan lembaga perbankan seperti 
halnya dengan BRI yang telah mempunyai motto peduli (care) terhadap lingkungan, maka di lingkungan pendidikan dan pelatihan diterapkan prinsip-prinsip berkelanjutan di dalam penyelenggaraan aktivitas sehari-hari. Sebagai contoh: dalam penggunaan fasilitas kerja meng-gunakan bahanbahan yang ramah lingkungan, menerapkan efisiensi penggunaan energi listrik, menerapkan pengelolaan sampah yang higienis, dan sebagainya.

\section{Upaya Peningkatan Tanggung jawab Peserta PPS BRI dalam Pelestarian Lingkungan mela-lui Peningkatan Empati}

Dalam rangka meningkatkan empati peserta PPS BRI harus diupayakan dapat tersentuh perasa-annya mana kala melihat keadaan lingkungan yang memprihatinkan. Upaya-upaya yang dapat dilakukan untuk meningkatkan empati, antara lain:

Pertama, mengembangkan kebersamaan dengan menggalang kerja sama dan gotong royong antara sesama peserta PPS BRI selama berlangsung pendidikan di lingkungan pusat pendidikan dan pelatihan.

Kedua, menginisiasi kesadaran peserta PPS BRI dalam hal menjaga fasilitas umum di lingkung-an pendidikan. Kesadaran ini akan menumbuhkan perasaan saling menjaga fungi-fungsi fasilitas umum bagi kepentingan bersama sehingga dapat meningkatkan empati.

Ketiga, penyebar luasan informasi berkenaan dengan aspek permasalahan lingkungan. Dalam konteks ini empati dapat dikuatkan dalam bentuk tindakan, misalnya: menyumbang musibah bencana alam, menyumbang kegiatan relawan lingkungan, dan menyumbang kegiatan bakti sosial.
3. Upaya Peningkatan Tanggung jawab Peserta PPS BRI dalam Pelestarian Lingkungan me-lalui Peningkatan Komitmen terhadap Lingkungan

Dalam konteks penelitian ini, maka untuk meningkatkan komit-men terhadap lingkungan peserta PPS BRI dapat dilakukan dengan upaya, antara lain:

Pertama, secara internal kelembagaan BRI sebagai mitra dalam pelayanan penyelengaraan pembangunan harus memperkuat kebijakan yang mengakomodir komitmen terhadap lingkungan. Kebijakan ini akan menjadi panduan bagi siapa pun yang bekerja sama dengan BRI.

Kedua, mengaktualisasikan kebijakan-kebijakan yang telah ada berkenaan dengan tanggung jawab dalam pelestarian lingkungan kepada peserta PPS BRI selama pen-didikan berlangsung.

Ketiga, menjaga konsistensi aktivitas keseharian di segenap sivi-tas penyelenggaraan pendidikan dan pelatihan di kampus dengan tidak bertentangan dengan prinsip-prinsip lingkungan, seperti: pelibatan dalam menjaga keindahan kampus, penghijauan kampus, dan kebersihan kampus.

\section{SARAN}

Berdasarkan kesimpulan penelitian ini dapat diajukan beberapa saran sebagai berikut:

Pertama, bagi Pusdiklat BRI. Dalam rangka meningkatkan tang-gung jawab peserta PPS BRI dalam pelestarian lingkungan, maka perlu dipertimbangkan kemungkinan dilakukan pengintegrasian materi tentang pembangunan berkelanjut-an ke dalam mata ajar yang telah ada tanpa mengurangi esensi kegiatan program pendidikan yang sudah berjalan. 
Kedua, bagi pimpinan BRI. Dalam rangka penguatan tanggung jawab dalam pelestarian lingkungan di kalangan internal BRI, maka perlu diaktualisasikan secara terus-mene-rus kebijakan internal kelembagaan BRI sebagai mitra pembangunan yang bervisi ramah lingkungan.

\section{DAFTAR PUSTAKA}

Baldwin, John D. and Janice I Baldwin. Behavior Principles in Everyday Life. New Jersey: Prentice Hall, 1986.

Benkhoff. "Ignoring Commitment is Costly: New Approaches Establish the Missink Link Between Organizational Commitment and Performance”, Human Relations. 50, (6), 1997., p. 3.

Bernard, Chester I. Buku Pegangan Fungsi Eksekutif, terjemahan. Rohmulyati Hamzah. Jakarta: PT Pustaka Binaman Pressindo,1982.

Bernes, Alison and Paul Thagard. Empathy and Analogy. Water-loo: Ontario, 1997: http: waterloo.ca/articles/pages/empathy.h tml.

Bloom, Benjamin S., et.al., Taxo-nomy of Educational Objec-tives: The Classification of Educational Goal. London: Logman Group Ltd., 1984.

Bower, Gordon M., Richard R. Bootzin., and Robert B. Zajone. Principles of Psy-chology Today. New York: Random House, 1987.

Carlson, Neil R. Psychology the Science of Behavior. Boston: Allyn and Bacon, 1990.

Davenport, Tom and Larry Prusak. Working Knowledge (1999), p.l. http:llwww. Compotenet. Org.br/slides allee 22/ tsldo htm).
Feitelson, Eran. "Introducing Environmental Equity Dimensions in the Sustainable Transport Discourse: Issues and Pitfalls",Transportation Rese-arch Part D 7 (2002) 99 - 118, Department of Geo-graphy, The Hebrew Univer-sity of Jerussalem, Mount Scopus, 91905, Jerussalem, Israel., p. 3.

Field, Tiffany M., et al. Review of Human Development. New York: McGraw-Hill, 1982.

Hadi, Sudharto P. Dimensi Ling-kungan Perencanaan Pemba-ngunan. Yogyakarta: Gadjah Mada University Press, 2001.

Munangsihe, Mohan. Sustainable Development Triangle. Washing-ton D.C.: Environmental In-formation Coalition, National Council for Science and the Environment, 2007.

Myers, David G. Psychology. New York: McGraw Hill-Book Company, 1983.

Nyle, Brady C. The Nature and Properties of Soil. New York: The Macmillan,1992.

Putrawan, I Made. Pengujian Hipo-tesis dalam Penelitian-Pene-litian Sosial. Jakarta: Rineka Cipta, 1990.

Salim, Emil. Lingkungan Hidup dan Pembangunan. Jakarta: Mu-tiara, 1983.

"Sustainable Development: An Indonesian Perspective”, Paper on Presen-ted at AISEC, Jakarta, 9-10 March 1989.

Shawa, Delery and Abdulla. "Organizational Commitment and Performance Among Guest Workers and Citizens of an Arab Country", Journal of Business Research, 56, 2003., p. 2. 
Singarimbun, Masri. "Metode dan Proses Penelitian”. Masri Singarimbun dan Sofian Effendi (ed). Metode Pene-litian Survai. Jakarta: LP3ES, 1987.

Slocum, John W. and Don Hellriegel. Fundamental of Organizatio-nal Behavior. Australia: Thomson, South Western, 2007.

Soemarwoto, Otto. Ekologi, Lingkungan Hidup dan Pembangunan Jakarta: Djambatan, 2001.

Suhatmansyah, "Hubungan antara Pendapatan Masyarakat, Perhatian terhadap Keles-tarian Fungsi DAS, dan Komitmen dalam Kelompok Tani dengan Perilaku Ma-syarakat dalam Rehabilitasi Lahan Kritis di SubDas Citarik Kabupaten Bandung, Tahun 2002” Sinopsis Disertasi. Jakarta: Program Pascasarjana, Universitas Negeri Jakarta, 2004.

Sudjana. Teknik Analisis Regresi dan Korelasi. Bandung; Tarsito, 1983.

Sugiyono. Metode Penelitian Kuantitatif, Kualitatif, dan $R$ \& D. Bandung: Alfabeta, 2006.

Suriasumantri, Jujun S. Filsafat Ilmu Sebuah Pengantar. Jakarta: Pustaka Sinar Harapan, 1998.

Stout, Kenneth and Allan Walker, Teams, Team Work and Team Building, The Manager Guide to Teams in Organizations. Singapore: Prentice-Hall, 1995.

Tudor, Child. Development. New York: McGraw-Hill Book Company, 1981.

Vaughan, Graham and Michael Hogg. Introduction to Social Psychology. Sydney: Prentice Hall, 1995.
Western, Drew. Psychology Mind and Brain and Culture. New York: John Wiley \& Sons, Inc., 1996.

Yani, Akhmad. Pengaruh Persepsi pada Iklim Organisasi, Pe-ngetahuan tentang Polusi Udara, Motivasi Hidup Se-hat terhadap Partisipasi dalam Pelestarian Fungsi Lingkungan Hidup (Survei di PT Aneka Tambang Tbk, 2009” Sinopsis Disertasi. Jakarta: program Pasca-sarjana, Universitas Negeri Jakarta, 2009. 